\title{
VISUAL STYLE OF 21 INTELECTUAL PROPERTY RIGHT (IPR) CERTIFIED LASEM BATIK MOTIFS AS THE EXPRESSION OF CULTURAL HYBRIDITY
}

\author{
Yunita Setyoningrum¹; Christine Claudia Lukman²; Sandy Rismantojo ${ }^{3}$ \\ 1,2,3Interior Design Design Study Program, Faculty of Art and Design, Maranatha Christian University \\ Jl. Surya Sumantri 65 Bandung 40164, Indonesia \\ 1'yunita.setyoningrum@art.maranatha.edu; ${ }^{2}$ christineclaudialukman@gmail.com; ${ }^{3}$ cemenk2001@gmail.com
}

Received: $15^{\text {th }}$ July 2019/ Revised: 30 $0^{\text {th }}$ July 2019/ Accepted: 07 $7^{\text {th }}$ August 2019

How to Cite: Setyoningrum, Y., Lukman, C. C., \& Rismantojo, S. (2019). Visual style of 21

Intelectual Property Right (IPR) certified Lasem batik motifs as the expression of cultural hybridity.

Humaniora, 10(3), 175-184. https://doi.org/10.21512/humaniora.v10i3.5680

\begin{abstract}
The problem in this research derived from the fact that many Lasem batik entrepreneurs nowadays had limited knowledge of the novel characteristics of Lasem batik and hardly aware of its geographical indication. The research objective was to identify how the cultural hybridity of Chinese-Javanese culture and Lasem geographical environment were reflected by both the Tionghoa Peranakan-descent and Javanese-descent artists through the visual signs in the batik design. The purposive samples used were 21 Lasem batik motifs made by Tionghoa Peranakan-descent and Javanese-descent entrepreneurs which already IPR-certified. The method used was a compositional interpretation by interpreting each batik motif composition according to its content (subject matter), color, spatial organization, and expressive content (the combined effect of subject matter and visual form). The finding reveals that Lasem visual style hybridity is generally visible in: (1) the use of Chinese subject matter combined with Javanese motifs, (2) the use of Chinese subject matter combined with local Javanese isen-isen (texture), and (3) the rich use of red (from Chinese batik visual style) combined with brown (from Javanese batik visual style). This finding can be used as a reference guide for latter Lasem batik entrepreneurs to maintain the particular characteristics of Lasem batik while developing other batik motifs innovation.
\end{abstract}

Keywords: visual style, lasem batik, lasem batik motifs, cultural hybridity

\section{INTRODUCTION}

Lasem is a district in Rembang, Central Java, located on the north coast of Java. Geographically, Lasem has coastal areas, plains, and valleys, as well as hills and mountains. Since the $13^{\text {th }}$ century, many Chinese merchants visited Lasem, and some of them later settled in Lasem and formed a Chinatown in the Dasun region or along the Babagan River. In the $14^{\text {th }}$ century, there had been a settlement colony around the Lasem River that became the center of trade activity (Unjiya in Lestari \& Wiratama, 2019).

The existence of Lasem as a batik production center, which began in 1401 Saka (1479 AD), was recorded in Babad Lasem by Pu' Santri Badra. He stated that Admiral Cheng Ho's crew named Bi Nang Un requested permission to Prince Wijaya Badra to settle in Lasem. Then, he returned to China to pick up his wife and take her to Lasem. In this new residence, Bi Nang Un's wife ( $\mathrm{Na} \mathrm{Li} \mathrm{Ni)} \mathrm{introduced}$ batik techniques to the locals. She made batik with phoenix, chrysanthemum, banji, old coins motifs in red (chicken blood red or abang getih pithik), which was the typical color of Chinese visual style. $\mathrm{Na} \mathrm{Li} \mathrm{Ni} \mathrm{also} \mathrm{taught}$ batik techniques to the natives in Lasem (Nurhajarini, Purwaningsih, \& Fibiona, 2015).

These motifs that originally derived from Chinese culture were then mixed with batik motifs from Javanese kingdoms in the hinterland (Yogyakarta and Surakarta), called vorstenlanden batik (Situngkir, 2009). It had already happened since the Islamic Mataram Kingdom controlled the north coast of Java that all employees and their families were required to wear clothes with Mataraman motifs. For economic purposes, the batik entrepreneurs in Lasem made clothes that had a mixture of Mataraman and coastal motifs, namely Pasir Kawung, Pring-Pringan, Lung-Lungan, Gunung Ringgit, Watu Pecah, Kendoro-Kendiri, Bledag Mataraman, Kawung Babagan, and so on. It can be said that since that time, there were Lasem batik clothes that have motifs from Chinese, Mataraman, and mixture of both.

Some of Lasem batik clothes nowadays are developed from classical batik clothes that are made by Tionghoa Peranakan-descendants in the early of $20^{\text {th }}$ century. They originally make batik with motifs and colors from Chinese visual style, but then combine with Javanese batik visual 
style. The hybridity of Chinese and Javanese visual styles on batik cannot be separated from the socio-cultural long history of the Lasem community, who has always been accustomed to cultural hybridity. This cultural visual style hybridity forms the geographical indication of Lasem batik.

TRIPs agreement article 22 has stated about protection on the geographical indication, which is a sign that indicates the origin area of an item due to geographical, environmental factors (natural and human factors), gives certain characteristics and qualities to the product (Rahmatullah, 2014). It is also important to consider that the novelty of geographical indication is not only identified from the existence of original producer, along with the physical and human environment characteristics of a given region, but also the characterization from its codification process and recognition through an intellectual property right (Sautier, Biénabe, \& Cerdan, 2011).

Unfortunately, many newcomer Lasem batik entrepreneurs nowadays do not thoroughly aware of the importance of Lasem batik geographical indication. The lasem batik industry had collapsed in the 1970s before it is rising again recently. During the downfall, many Lasem batik entrepreneurs shut down their businesses, while their children move out of town, leave the batik businesses to end. This situation causes collective memory discontinuity of the latter batik entrepreneurs' generation. When the batik industry is rising again, many entrepreneurs have limited knowledge of the Lasem batik characteristics. Thus, many of these latter Lasem batik entrepreneurs imitate motifs and design from other regions to increase sales and enrich their batik motifs repertoire, when, in fact, unwittingly eliminates the characteristic of Lasem batik. On the other hand, batik entrepreneurs from other regions often use Lasem batik motifs without giving royalties or asking for permission.

Batik has also been acknowledged as Indonesian cultural heritage by UNESCO, particularly hand-written batik. Hence it should be preserved and protected. The specific characteristic that the Indonesian government would like to highlight is the Indonesian traditional practice of dying cloth through the wax-resist method. To preserve and protect Lasem Batik, Rembang district's government has been supporting batik entrepreneurs to certify their batik motifs, which still have a geographical indication. At this moment, 21 Lasem batik motifs have been certified under the HKI (Hak Kekayaan Intelektual or Intellectual Property Rights). These certified Lasem batik motifs are protected by UUHC (Undang Undang Hak Cipta or Copyright Act) Number 19 of 2002.

Based on the researchers' concern to raise latter batik entrepreneurs' awareness on the importance of Lasem batik geographical indication, this research selected these 21 HKI-certified Lasem batik motifs as purposive sampling, considering that they have vivid geographical indication. The objective is to identify how the cultural hybridity of Chinese-Javanese culture and Lasem geographical environment are reflected by both the Tionghoa Peranakan descent and Javanese-descent artists, through the batik design visual style. In this research, the researchers propose that the cultural hybridity in the visual style should be redefined to promote Lasem batik geographical indication. The research finding then can be used as a reference guide for latter Lasem batik entrepreneurs to maintain the particular characteristics of Lasem batik while developing other batik motifs innovation.

The visual style is the medium of expression within a group to communicate and consolidate certain values of religion, social, and moral life. Moreover, visual style can be used as a basis for measuring innovation and individuality in a particular work. For cultural historians or philosophers of history, the visual style is a cultural manifestation as a whole since it reflects the 'inner form' of collective thinking and feeling. Thus, it is necessary to examine the ways and reasons for a visual style created and used to communicate and affirm the identity of a social group to other groups. Chan (2015) has mentioned that scholars and philosophers have developed a notion of 'style' and used it to help analyze beauty and explore methods of creation, and to distinguish differences between individual artists, groups, and schools. Earlier, Schapiro has argued that it is a system of forms with meaningful qualities and expressions that show the personality of the artist and the group's point of view (Walker, 2010).

Visual style hybridity is a cross-cultural design that occurs due to displacement, ambiguity, and irony. Steiner (1995) has suggested that it is important to avoid misinterpretation of the hybrid visual design. Hence, the message in each design should be clear and presented without losing the meaning and attitude of the original concept (McMullen, 2016). They explain three stages of the cross-cultural design process, first is a quotation. At this stage, someone uses a foreign image for their quaintly exotic flavor, as decoration, therefore close to plagiarism, employing icons without necessarily understanding them. The second stage is mimicry. It is working in the style of an artist to understand to some degree how and why the model is done. The purpose is more towards re-creation than reproduction. Furthermore, the third stage is transformation. In this stage, influence has been assimilated, and once the foreign becomes personal and natural (Steiner, 1995).

This research analyzes the visual style of each batik cloth by its three main elements, which are image (motif and isen-isen or texture), color, and composition or spatial organization. Compared to batik Pesisir from the other northern coastal town, Lasem batik has its distinctive dye color, images, and composition (Lukman, Setyoningrum, \& Rismantojo, 2018).

Image, as the first main element on batik, has a variety of forms ranging from representational (realism), stylization, up to abstraction (objective and non-objective abstraction). Representational images look recognizably similar to something in the real world since realism is the precise, detailed, and accurate representation art of the visual appearance of objects and scenes. Stylization refers to a visual depiction, which represents an object without a full attempt and accurate representation of an object's realistic appearance include simplifications in shape, lines, color, pattern, and surface details. Stylized image is divided into two categories that are exaggerated stylization and minimalistic stylization. Objective abstraction comes from reality then distorted (enlarged, cropped, fragmented, simplified, stretched), while non-objective abstraction does not refer to an object but focuses on the basic principles and elements of art (Radford, n.d.).

While color, the second element, is the most expressive visual element that has psychological, associative, and connotative disparate effects in different places because of cultural distinction that is often subjectively perceived. Since color quality can affect human emotions, Kobayashi (2009) has developed a 'color image scale' to understand the effect of a color or combination of colors on human emotions through 180 adjectives (image word database). He has developed a single image and color combination image 
scale of 130 colors (120 chromatic and ten achromatic), arranged by hue and tone (Figure 1). The colors in this scale can be grouped into colors with vivid tones (V and $\mathrm{S}$ ), bright tones (B, P, Vp), sombre tones ( Lgr, L, Gr, Dl), and dark tones (Dp, Dk, Dgr). The color combination image scale shows subtle differences between divergent color combinations arranged according to their character; warm or cool, soft or hard, and clear or dull (Figure 2). This scale elaborates the colors in 13 character groups; pretty, casual, dynamic, gorgeous, romantic, natural, elegant, classic, clear, cool casual, chick, dandy, and modern (Kobayashi, 2009).

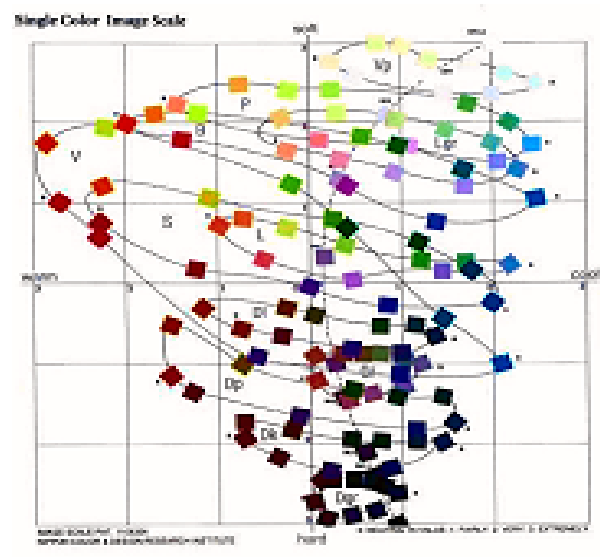

Figure 1 Single Color Image Scale

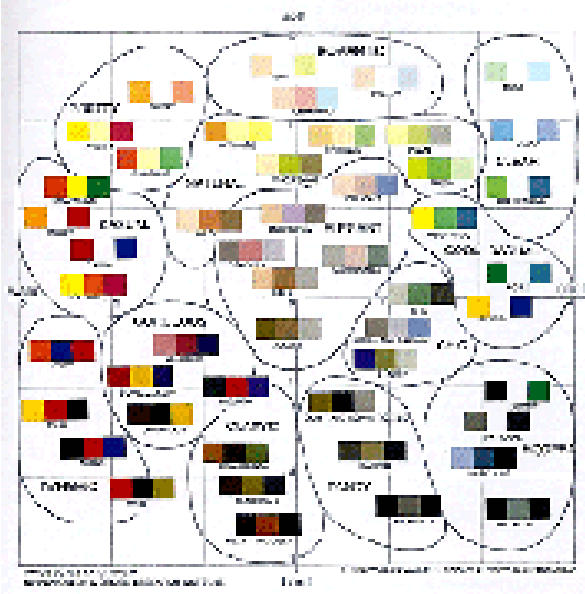

Figure 2 Color Combination Image Scale

The third element, composition or spatial organization, is the arrangement and structure of all visual elements in accordance with the principles of organizing to produce unity as a whole. Things that need to be considered in making the composition are emphasis and unity. A composition can be dense, medium, or quiet, but must have a clear visual hierarchy. The size of elements in the plane and relationships with other elements is an important perceptual factor because it determines the visual hierarchy. The dense, medium and quiet composition will produce a different impression. Dense composition tends to be crowded and festive, but if it does not have a clear visual hierarchy, it will look chaotic. On the contrary, the quiet composition tends to be elegance, but if it does not have a strong focal point, it will look like unfinished artwork (Zajko, 2012).

\section{METHODS}

21 Lasem batik motifs are analyzed through the compositional interpretation method. The decision to choose these 21 batik motifs is because these 21 pieces have already chosen by the community and also the government among the wide range of existing Lasem batik motifs. First, the researchers interpret visual style in the form of the image used as the main motif and isen-isen, color, and spatial organization. Second, the researchers identify the subject matter used in each batik motif design and interpret its expressive content (the combined effect of subject matter and visual form). Then, the researchers analyze the Chinese-Javanese hybridity that is found in the visual style and classified them according to the cross-cultural design process stage. The researchers' intention are (1) to list the various application of visual style of the image (main motif and isen-isen to create texture), color, and the spatial organization in each batik design; (2) to identify the visual culture hybridity subject matter found in each batik design; (3) to classify the stage of cross-cultural process used.

\section{RESULTS AND DISCUSSIONS}

This section describes the compositional interpretation analysis of 21 batik motifs. consisting of (1) the visual style used in the form of image, color, and spatial organization; (2) the subject matter and its expressive content (the combined effect of subject matter and visual form); (3) the Chinese-Javanese hybridity found in the visual style with the explanation of its cross-cultural design process stage.

The first motif is Bledag Kipas by Santoso Hartono, who is a Tionghoa Peranakan-descent entrepreneur. The subject matter of this motif is the fan between vines that represents the expressive contents of dynamic and cheerful. The visual style of Bledag Kipas can be seen in the style of fan and vines pattern. It is an objective abstraction, while isen-isen in the fan area is a non-objective abstraction. The color combination image is casual (red, brown, violet, and white). The spatial organization tends to be dense. The fan is a focal point because of its large size and has more detail. The visual culture hybridity in fan, as the subject matter, comes from Chinese culture and visual art (symbol of goodness and wisdom) visualized in the personal style of the artist. And the stage of cross cultural design process is transformation. The Bledag Kipas can be seen in Figure 3.

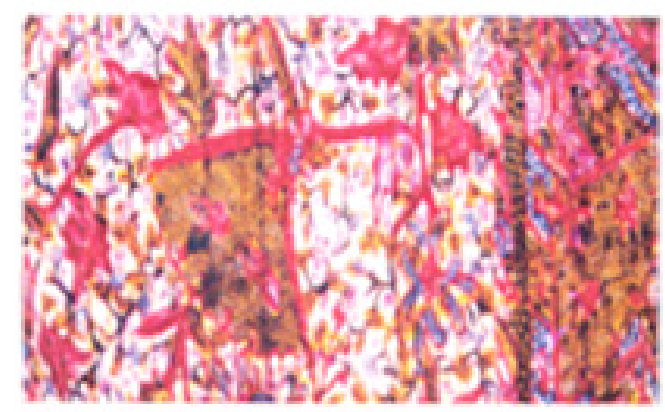

Figure 3 Bledag Kipas by Santoso Hartono 
The second motif is Lasem Pring-Pringan Bang Biru by Santoso Hartono. The subject matters of its motif are bamboo stems and leaves that show the expressive contents of cheerful, subtle, and feminine. The visual style of bamboo stems and leaves is stylization, while isen-isen is a non-objective abstraction. The color combination image is romantic (soft blue, red, and white). The spatial organization is dense. The bamboo stems and leaves become focal points because of their large size, and the color is in contrast to the background. The visual culture hybridity of Bamboo, as the subject matter, comes from Chinese culture and visual art (symbol of longevity, strength, and virtue) visualized in the personal style of the artist. While the stage of the cross-cultural design process is transformation. The motif of Lasem Pring-Pringan Bang Biru can be seen in Figure 4.

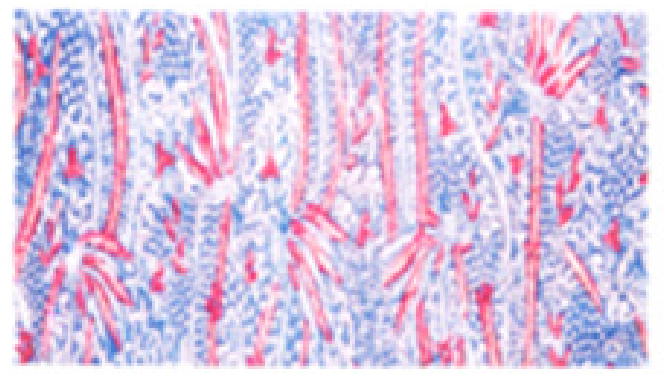

Figure 4 Lasem Pring-pringan Bang Biru by Santoso Hartono

The third motif is Ceplok Piring Sekar Peksi Abangan belongs to Fathur Rochim, who is a Javanesedescent entrepreneur. The subject matter of this motif is flowers (gardenia) and birds with the expressive content of feminine, graceful, subtle, and elegant. The visual style of flowers and birds is stylization, while isen-isen (ceplok pattern) is an objective abstraction that refers to the small flowers. The color combination image is gorgeous (deep red monochromatic) with a spatial organization that is dense. Flowers and birds are the focal points because of their detailed form and size. The combination of flowers and birds image (a subject matter from the Chinese painting genre called hua-niao), with isen-isen, is derived from hinterland batik (ceplok pattern). The artist draws the subject matter and isen-isen in his personal style. While the stage of the cross-cultural design process is a mimicry of the ceplok pattern hua-niao image. It can be seen in Figure 5.

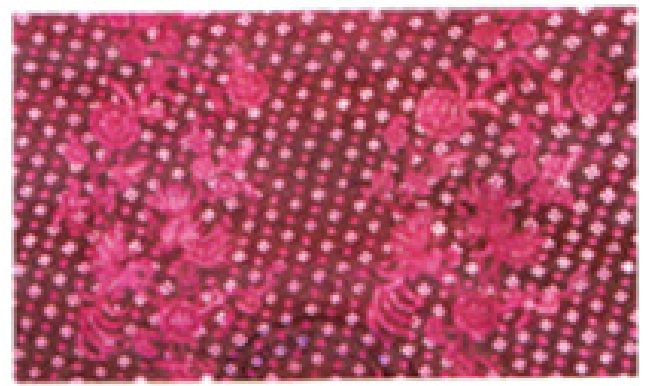

Figure 5 Ceplok Piring Sekar Peksi Abangan by Fathur Rochim
The fourth motif is Lasem Gunung; Ringgit Bang Biru belongs to Fathur Rochim. The subject matters of this motif are flower bouquets and old money coins that express the elegant. The visual style of flower bouquets is stylization, while isen-isen (gunung ringgit) is an objective abstraction that refers to old money coins. The color combination image is elegant (broken white, reddish-brown, black) with the spatial organization that is dense. Flower bouquets are the focal point because of their size and vivid color. The visual culture hybridity of this motif can be seen from the combination of a flower bouquet (from Tionghoa Peranakan visual style) with gunung ringgit (from Javanese Lasem visual style). The stage of the cross-cultural design process is shown from the quotation of flower bouquet from Tionghoa Peranakan visual style, and gunung ringgit pattern from Javanese Lasem visual style. Figure 4 shows the motif of Lasem Gunung; Ringgit Bang Biru belongs to Fathur Rochim (Figure 6).

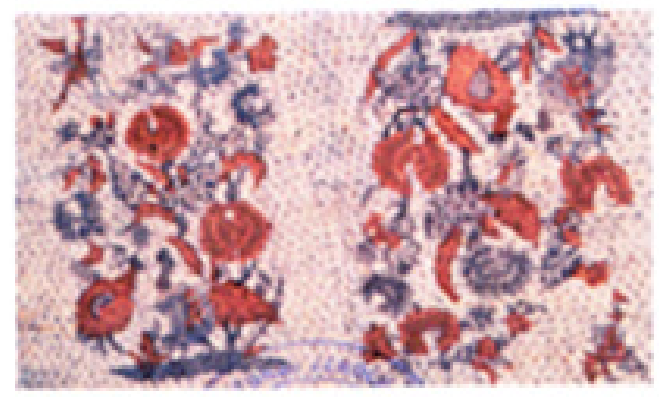

Figure 6 Lasem Gunung; Ringgit Bang Biru by Fathur Rochim

The fifth motif is Lerekan Ceplok Benik Sekar Srengrengan belongs to Fathur Rochim. The subject matter of this motif is flower bouquet with kawung and lerek (parang rusak) pattern with expressive content of aristocratic and elegant. The visual style of flower bouquets is stylization; the kawung pattern is an objective abstraction that refers to kawung fruits, while the lerekan pattern is a non-objective abstraction. The color image combination of it is elegant (broken white, dark brown, red, orange, and blue). The spatial organization is very dense so that the image of flower bouquets overlap kawung and lerek pattern. Flower bouquets are the focal point because of their vivid color. The visual culture hybridity is shown in the combination of a flower bouquet (influenced by Tionghoa Peranakan visual style) with kawung and lerek (from Yogyakarta and Solo batik visual style). The stage of the cross-cultural design process can be seen from the quotation of flower bouquet from Tionghoa Peranakan visual style, kawung, and lerek patterns from the hinterland batik visual style. Lerek is a mimicry of Parang Rusak's motives from inland batik. This motif can be seen in Figure 7.

The sixth motif is Lasem Lokcan Watu Pecah belongs to Naomi Susilowati, who is a Tionghoa Peranakandescent entrepreneur. The subject matters of this motif are a dragon, phoenix, flowering plants, and gravels. Those contents show the ancient, oriental, elegant, and story-like. The visual style of the dragon, phoenixes, and flowering plants is stylization, while watu pecah (broken pieces of stones or gravels) is an objective abstraction. The color combination image is dynamic (broken white, red, and blue) with a spatial organization that is dense. Dragon is the 
focal point because of its size and vivid color. It also shows the visual culture hybridity because of the combination of flower bouquet, dragon, and phoenix motifs (influenced by Tionghoa Peranakan visual style) and watu pecah pattern from Javanese Lasem visual style. Quotation of the dragon, phoenixes, flowering plants from Chinese visual style, and gravels pattern from Javanese Lasem visual style shows the stage of the cross-cultural design process. The stage of cross-cultural design process is transformation. This kind of motif can be seen in Figure 8 .

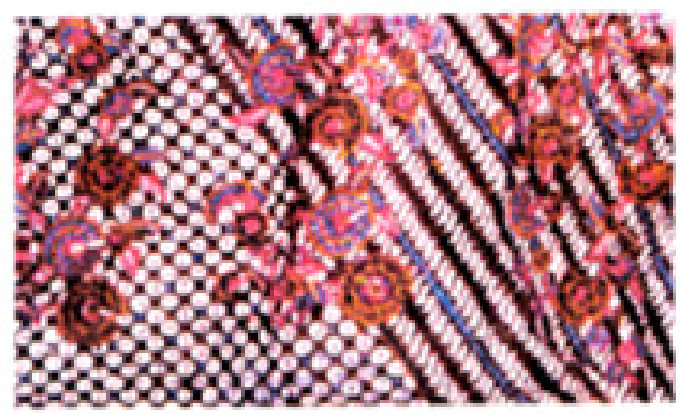

Figure 7 Lerekan Ceplok Benik Sekar Srengrengan by Fathur Rochim

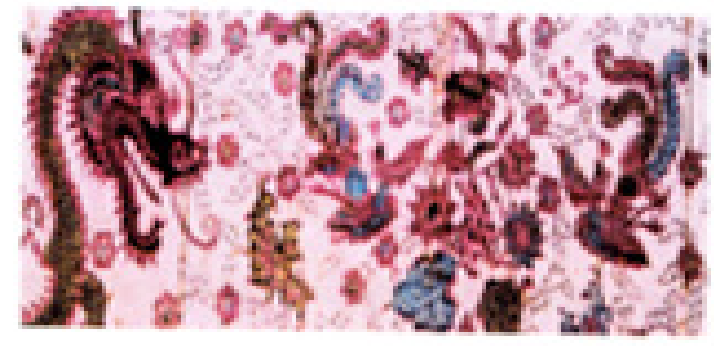

Figure 8 Lasem Lokcan Watu Pecah by Naomi Susilowati

The seventh motif is Lasem Sekar Jagad Es Teh belongs to Naomi Susilowati. The visual style of flowers is an objective abstraction. The color combination image is classic (red, beige, broken white, and dark brown) with a very dense spatial organization. There is no focal point here. Sekar Jagad pattern comes from the visual style of Solo and Yogyakarta but visualized by the personal style of the artist, who is Naomi Susilowati. The stage of the cross-cultural design process is transformation. It can be seen in Figure 9.

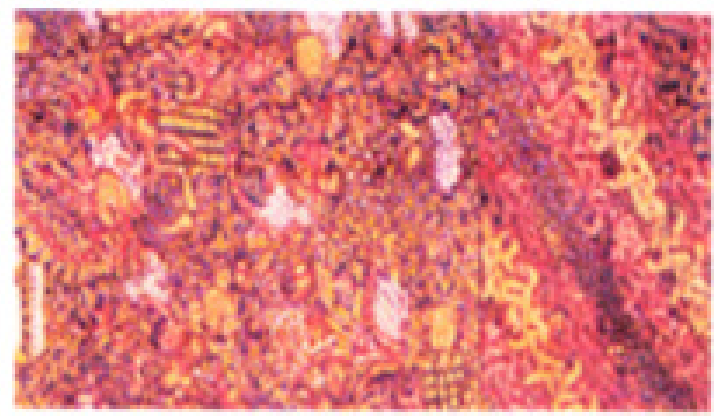

Figure 9 Lasem Sekar Jagad Es Teh by Naomi Susilowati
The eighth motif is Lasem Penutup Pintu Lokcan belongs to Naomi Susilowati. The subject matters of this motif are carp fishes and Chinese auspicious motifs. It has expressive contents of ancient, oriental, jocular, and cheerful. The visual style of carp fishes and other objects (Chinese auspicious images: jar, conch shell, endless knot, longevity stone) is stylization. The combination color palette image is chic (broken white and dark blue) with a moderate spatial organization. Fishes are the focal point because of their size. The subject matter comes from Chinese culture and visual style but visualized in the personal style of the artist that makes it has visual culture hybridity. The stage of the cross-cultural design process is transformation. It can be seen in Figure 10.

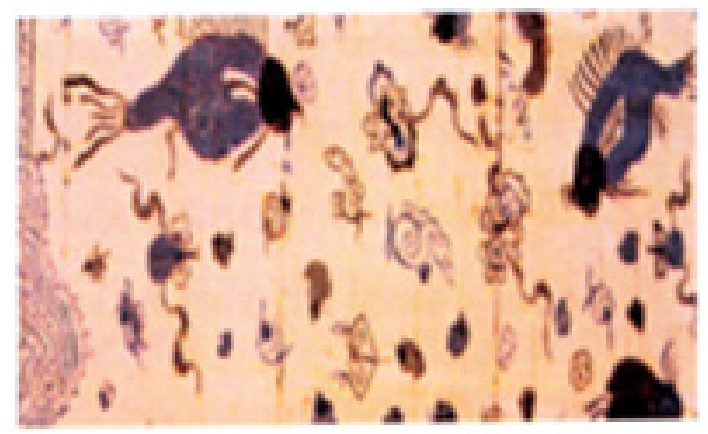

Figure 10 Lokcan Lasem Penutup Pintu by Naomi Susilowati

The ninth motif is Lasem Sekar Jagad Latoh Alge belongs to Naomi Susilowati. The subject matters of it are the various flowers and alga that have expressive content of dynamic. The visual style of flower and alga is an objective abstraction, while isen-isen is a non-objective abstraction. Color combination image is casual (beige, dark brown, red, white, and blue) with a very dense spatial organization. There is no focal point here. Sekar Jagad motif and latoh or alga motifs (from Javanese Lasem) visualized by the personal style of the artist (Naomi Susilowati, a Tionghoa Peranakan woman) that creates the visual culture hybridity. While the stage of the cross-cultural design process is transformation. The motif can be seen in Figure 11.

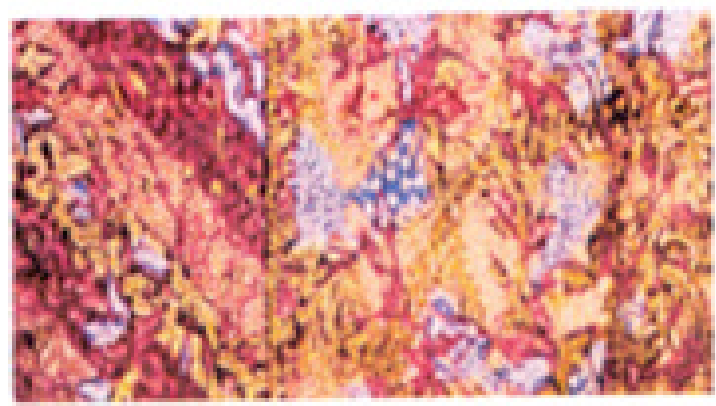

Figure 11 Lasem Sekar Jagad Latoh Algae by Naomi Susilowati

The tenth motif is Kendoro-Kendiri Ukel belongs to Anisa, a Javanese-descent entrepreneur. The subject matters of this kind of motif are flowering twiner and ukel pattern 
(like sprouts) with expressive content of classical. The visual style of flowering twiner is stylization, while ukel pattern (similar to beans sprouts) is an objective abstraction. Color combination image is dynamic (black, brown, red, and beige) with a very dense spatial organization. Moreover, there is no focal point here. The visual culture hybridity of Kendoro-Kendiri and ukel motifs are the classic motif of Lasem batik but visualized by the personal style of the artist, while the stage of the cross-cultural design process is transformation. Figure 12 shows the Kendoro-Kendiri Ukel motif.

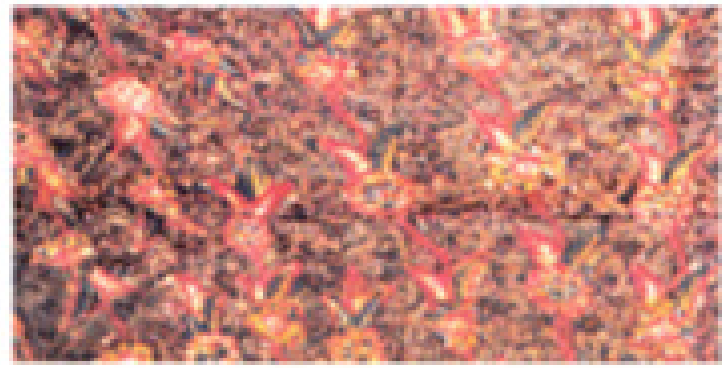

Figure 12 Kendoro-Kendiri Ukel by Anisa

The eleventh motif is Lasem Sekar Jagad Latoh Biron. The visual style of various flowers and alga is stylization, while isen-isen is a non-objective abstraction. Color combination image is dynamic (dark blue, red, brown, and broken white) with a spatial organization that is very dense. There is no focal point here. Sekar Jagad and latoh motifs are the classic motif of Lasem batik but visualized by the personal style of the artist that creates the visual culture hybridity. The transformation is the kind of stage of the cultural-cross design process. Its motif can be seen in Figure 13.

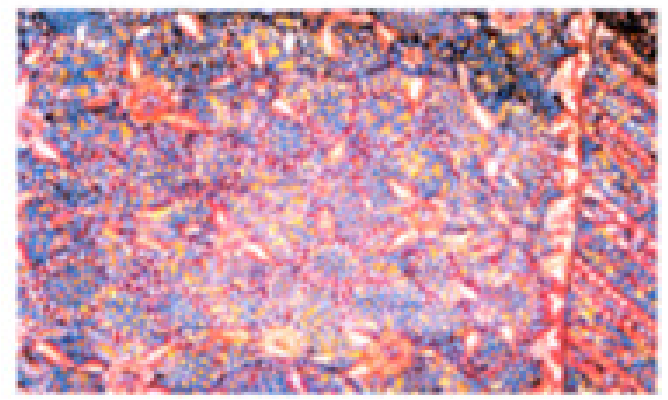

Figure 13 Lasem Sekar Jagad-Latoh Biron

The twelfth motif is Lasem Endhog Walang belongs to Sugiyem, a Javanese-descent entrepreneur. The subject matters of this motif are phoenixes, plants, and locust's eggs with expressive content of classical. The visual style of phoenix is stylization, while locust eggs are an objective abstraction. Color combination image is a classic (white, dark brown, brown, black, and blue.) with a very dense spatial organization. Phoenix is the focal point because of its size and dark color. The visual culture hybridity can be seen in the phoenix image of Chinese visual style that is visualized through artist's (a Javanese woman) personal style, then combined with Javanese Lasem locust's eggs motif. The stage of the cross-cultural design process of this batik is mimicry. This kind of batik can be seen in Figure 14.

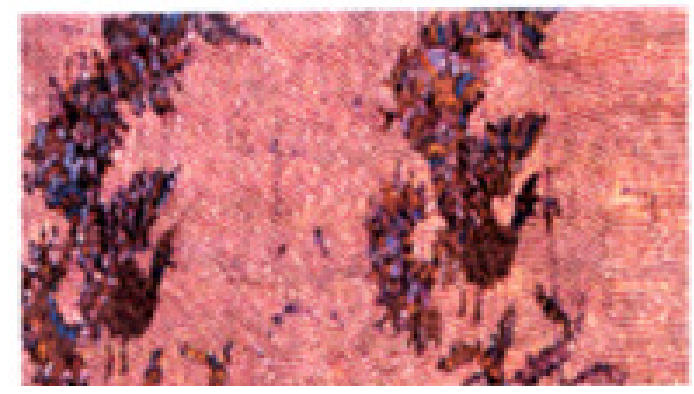

Figure 14 Lasem Endhog Walang by Sugiyem

The thirteenth batik motif of Lasem is Lasem Gunung Ringgit Sisik Trenggiling belongs to Sugiyem. The subject matter of this kind of batik is ancient coins that have orderly and tidy expressive content. The visual style of coins is an objective abstraction. Color combination image is casual (white, red, and chrome) with a very dense spatial organization. There is no focal point here. The visual cultural hybridity can be seen from the combination of coins from Javanese batik motifs with red and chrome from the color of Tionghoa Peranakan batik. Gunung ringgit (mountain of coins) pattern is usually combined with pringringan, flower bouquet, and so on, but Sugiyem makes a design that only displays gunung ringgit. There is no crosscultural design process in this motif of batik. The design can be seen in Figure 15.

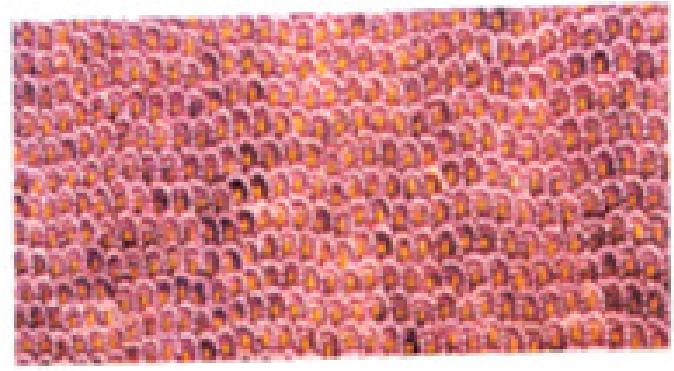

Figure 15 Lasem Gunung Ringgit Sisik Trenggiling by Sugiyem

The fourteenth batik motif is Parang Sekar Es Teh belongs to Abdul Rouf, a Javanese-descent entrepreneur. The subject matters of this kind of batik are flowers and parang motif that have expressive content of classical and aristocratic. The visual style of flowering twiner is stylization, while parang motifs are a non-objective abstraction. The color combination image is classic (dark brown, brown, violet, and broken white with a very dense spatial organization. There is no focal point here. The visual culture hybridity appears by combining the sekar motif (from the visual style of Tionghoa Peranakan batik) with the parang motif (from hinterland batik). These motifs are visualized by the personal style of the artist. The stage of the cross-cultural design process is transformation. It can be seen in Figure 16.

The fifteenth motif is Latohan Abangan belongs to Abdul Rouf. The subject matter of this motif is the 
flowers with alga with expressive content of cheerful, modern, simple, and feminine. The visual style of flowers is stylization, while alga (isen-isen) is an objective abstraction. Color combination image is casual (broken white and red) with a dense spatial organization. Flowers are the focal points because of their size and color (in contrast with the background). This motif creates the visual culture hybridity by combining the flower motif (from Tionghoa Peranakan batik visual style) with the latoh motif (classical motif of Lasem batik). The artist draws these motifs in his personal style. The stage of the cross-cultural design process of this batik motif is transformation. It can be seen in Figure 17.

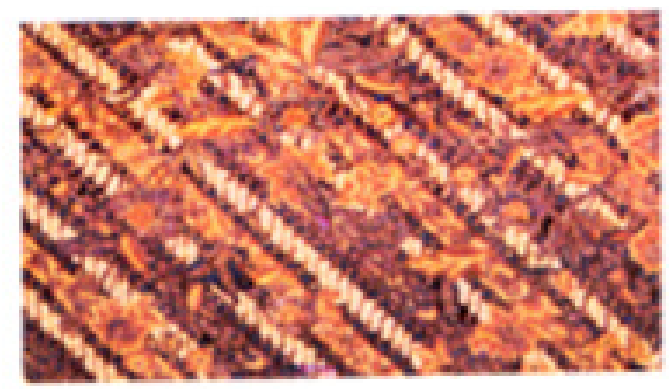

Figure 16 Parang Sekar Es Teh by Abdul Rouf

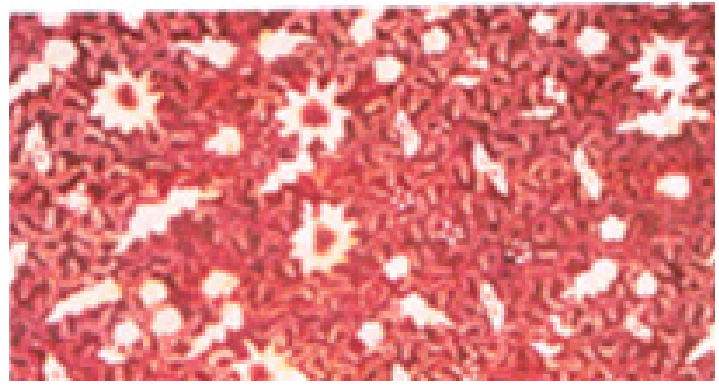

Figure 17 Latohan Abangan by Abdul Rouf

The sixteenth motif is Lasem Pasiran belongs to Widji Suharto, a Tionghoa Peranakan-descent entrepreneur. The subject matters are flowering plants and pasiran motifs that have expressive content of cheerful and feminine. The visual style of flowering plants is stylization, while pasiran (sand) motifs are a non-objective abstraction. Color combination image is romantic (white, brown, dark brown, and blue) with a dense spatial organization. Flowering plants are the focal points because of their size and vivid color. The combination of flowering plants motif (from Tionghoa Peranakan visual style) with pasiran motif (from Javanese Lasem visual style) makes the visual culture hybridity. The stage of the cross-cultural design process can be seen in the quotation of motifs from Tionghoa Peranakan and Javanese Lasem batik visual styles. It can be seen in Figure 18 .

The seventeenth motif is Lasem Lerek Lunglungan belongs to Widji Suharto. The subject matters Lunglungan (twiner) and lerek motifs with expressive content of elegant and classical. The visual style of the lunglungan motif is stylization, while the lerek motif is a non-objective abstraction. Color combination image is gorgeous (dark brown, brown, and pale yellow) with a dense spatial organization. There is no focal point here. It makes the visual culture hybridity by combining the lunglungan motif (from Tionghoa Peranakan batik) with the lerek motif(from hinterland batik). The stage of the cross-cultural design process is seen by the quotation of motifs from Tionghoa Peranakan and Javanese batik visual styles. Figure 19 shows this kind of motif.

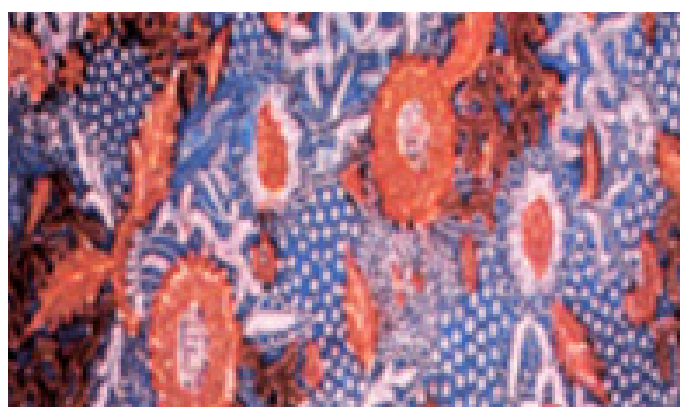

Figure 18 Lasem Pasiran by Widji Suharto

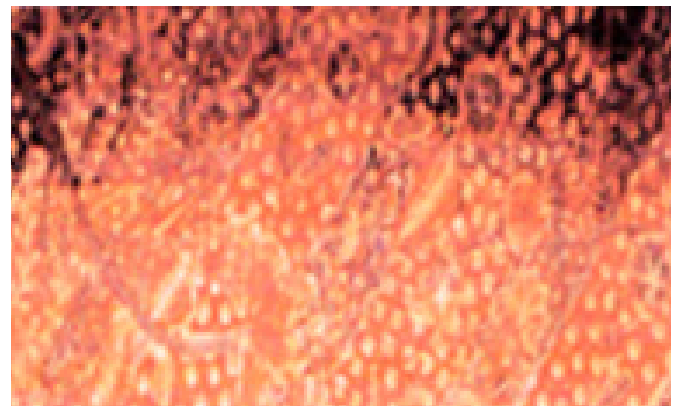

Figure 19 Lasem Lerek Lunglungan by Widji Suharto

The eighteenth motif is Lasem Latohan Kembang Kamboja Biron belongs to Widji Suharto. The subject matters of this batik motif are Plumeria flowers and alga that has expressive content of feminine, cheerful, and cute. The visual style of kembang kamboja (plumeria or frangipani) is stylization, and the latohan motif is an objective abstraction. Color combination image is elegant (white, violet, and deep violet) with a very dense spatial organization. Plumerias are the focal point because of their size and color (in contrast with the background). A combination of kembang kamboja (plumeria) motif from the artist's personal style with the latohan motif from Javanese Lasem batik visual style creates visual culture hybridity. The stage of the crosscultural design process is transformation. The artist draws the motifs in his personal style. The motif can be seen in Figure 20 .

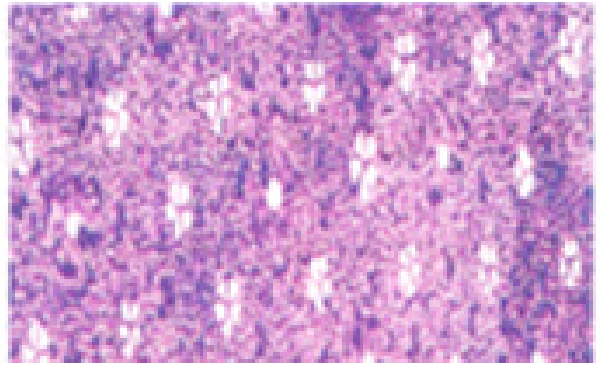

Figure 20 Lasem Latohan Kembang Kamboja Biron by Widji Suharto 
The nineteenth motif is Lasem Lerek Kawung Mlathi belongs to Abdul Rouf. The subject matters of this batik motif are flowering plants, alga, and kawung motifs that have expressive content of classical and aristocratic. The visual style of flowering plants is stylization, while alga and kawung motifs are an objective abstraction. Color combination image is gorgeous (red, black, brown, and blue) with a very dense spatial organization. Flowering plants are the focal points because of their size and vivid color. Combination of flowering plants motif (from Tionghoa Peranakan batik) with latohan (from Javanese Lasem batik), and kawung (from hinterland batik) visual styles creates the visual culture hybridity. The stage of the cross-cultural design process of this motif can be seen from the quotation of motifs from Tionghoa Peranakan, Javanese Lasem, Yogyakarta, or Surakarta batik motifs. Figure 21 shows an example of this motif.

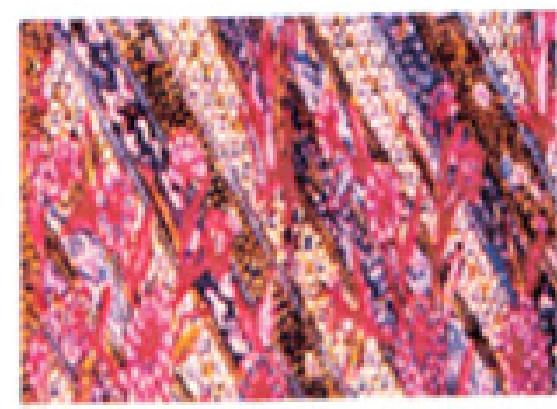

Figure 21 Lasem Lerek Kawung Mlathi by Abdul Rouf

The twentieth motif is Lasem Lerek Parang Sekar Srengrengan belongs to Paul Susanto, a Tionghoa Peranakan-descent entrepreneur. Subject matter: Flowering plants and lerek motifs that have expressive content; elegant, aristocratic, feminine, and graceful. The visual style of flowering plants is stylization, and the lerek parang motif is a non-objective abstraction. Color combination image scale is gorgeous (white, ochre, red, blue, and brown) with a very dense spatial organization. There is no focal point here. The visual culture hybridity can be seen from the combination of flowering plants motif (from Tionghoa Peranakan batik visual style) and parang motif (from hinterland batik visual style). Parang motif visualized in the personal style of the artist as the Tionghoa Peranakan man). The stage of the cross-cultural design process is by the quotation of Tionghoa Peranakan batik visual style and Yogyakarta/ Solo batik visual style. Figure 22 shows this kind of batik.

The last motif is Goyang Karawang (Karawang Cakar) belongs to Fathur Rochim. The subject matters of this motif are fish and water plants with the expressive content of cheerful and jocular. The visual style of fish and plants is stylization, while isen-isen (cakar pattern) is objective abstraction (refers to scratch of bird claw). Color combination image is chic (black or dark blue and white) with a dense spatial organization. Fish is a focal point because of its size. The artist might draw fish because he is familiar with maritime life, but he might also draw fish because he often sees it in coastal batik. In Chinese culture, fish symbolizes good fortune and longevity. The artist draws the subject matter and isen-isen in his personal style. The artist uses transformation in the stage of the cross-cultural design process. It can be seen in Figure 23.

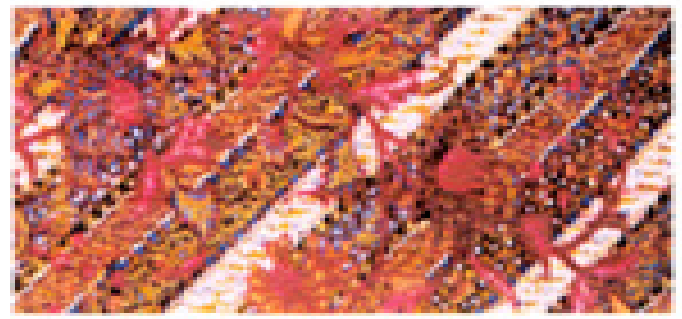

Figure 22 Lasem Lerek Parang Sekar Srengrengan by Paul Santoso

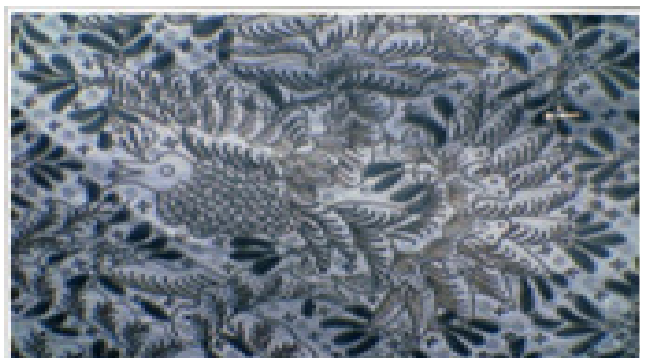

Figure 23 Goyang Karawang (Karawang Cakar) by Fathur Rochim

The research findings on the used subject matter are that almost all of the 21 batik designs use Tionghoa Peranakan-influenced subject matters, except for the coins (ringgit, which is the ancient money of Dutch era). The motifs from Tionghoa Peranakan visual culture are usually combined with the local motif of Javanese batik. The most frequent subject matter used in batik is flowers that combine with other images such as coins, birds, kawung, lerek (from Javanese batik motifs), algae, and abstract patterns. Flower motifs come from the visual style of Tionghoa Peranakan batik, so it can be said that the subject matter of Lasem batik is heavily influenced by Tionghoa Peranakan batik.

The combination of flowers with Javanese batik motifs shows the influence of cultural hybridity, while a combination of flowers and birds comes from a genre of Chinese painting (hua niao or flower and bird genre). Fish appears on batik by Fathur Rochim and Naomi Susilowati. In Batik Goyang Karawang, Fathur Rochim (Javanese man) chooses fish because he is affected by geographical condition Lasem that is located near the beach. According to him, fish is merely a typical animal that is often found at Lasem beach. It might also be because he frequently finds fish imagery in Tionghoa Peranakan batik, but never understands its symbolic meaning. On Batik Lokcan Lasem Penutup Pintu, Naomi Susilowati (Indonesian-Chinese woman) uses fish images because of its symbolic meaning in Chinese culture. Fish symbolizes abundance, unity, fidelity, and affluence. Thus, she draws fish swimming in celestial cosmic filled with other auspicious symbols such as conch, vase, endless knot, lotus, and so on.

Other subject matters derived from Chinese symbols are bamboo, fan, and dragon with phoenix. Bamboo symbolizes longevity, strength, and virtue; fan means goodness and wisdom, while dragon with phoenix symbolizes love, harmony, and togetherness. The interesting thing in Batik Lasem Lokcan Watu Pecah is the combination of dragon and phoenix motifs with the pattern of watu pecah, which refer to Daendels' history of making highway that make people along the northern coast of Java 
(including Lasem) suffer. This shows Naomi Susilowati's attempt to localize the Chinese symbol: "long feng cheng xiang" (dragon and phoenix bird bring blessings). The same thing is found in the Batik Endhog Walang created by Sugiyem, who placed phoenix (from Chinese visual culture) in a localized context (rice field in Lasem filled with locust eggs).

Unlike Naomi, Sugiyem, a Javanese artist, puts phoenix birds in the rice field filled with locust eggs on her batik design, because she often sees birds alongside with locusts in rice fields. Sugiyem creates a new meaning of prosperity through the image of birds that can eat locust eggs that much through her experience as part of an agrarian society. She draws phoenix birds on her batik design simply because it is the image that is often seen in Tionghoa Peranakan batik in Lasem.

The research finding on the used color is that the color combination images used in the 21 batik design are mainly casual, gorgeous, elegant, dynamic, classic, romantic, and chic. The most widely used color combinations are in the warm area of the Kobayashi color scale. White or broken white are often found in batik because while it is the natural color of the fabric, it is also sometimes be used as the dominant visual element. The dominant colors of these 21 batik motifs are red and brown. Both colors are influenced by Tionghoa Peranakan and Javanese batik visual styles. The other favorite color is blue, which they use to identify the classic batik motifs such as Tiga Negeri (red, brown, and blue), Kelengan (white and blue), and Lokcan (white and blue). Other colors are used as an effort to create innovation in Lasem batik motifs (Maulany \& Masruroh, 2017).

The research finding on the spatial organization is that these 21 batik designs have typically dense characteristics. This attitude shows the tendency of disliking the empty space or horror vacui (fear of emptiness). In batik design, horror vacui is represented by the effort to fill the entire surface with isen-isen (Lee, 2016). The preference for this kind of spatial organization is in line with the character of Lasem society that considers togetherness as a positive thing.

The research finding on the cross-cultural design process stage is that 12 of these 21 batik designs can be classified as transformation stage, indicated by the assimilating process of Tionghoa Peranakan and Javanese visual style into their personal style. Six artists are still in the quotation stage, which directly takes the motifs from Tionghoa Peranakan and Javanese batik without further interpretation, while two artists perform mimicry on Tionghoa Peranakan and Javanese batik motifs by interpreting and adapting it to their personal taste. Only one motif, Batik Lasem Gunung Ringgit Sisik Trenggiling that does not show any indication of hybridity. It can be said that most artists have actually tried to combine two visual styles of batik (Tionghoa Peranakan and Java batik) or create a certain visual style of batik (Tionghoa Peranakan style or Javanese style) with his/her personal style.

\section{CONCLUSIONS}

Upon the compositional interpretation and visual content analysis result, this research concludes that the 21 Lasem batik motifs are strongly influenced by Tionghoa Peranakan's visual culture, in particular on the subject matter and use of color. On the subject matter, Tionghoa Peranakan and Javanese cultural hybridity can be seen in the combination of Chinese subject matter with Mataraman patterns (kawung, parang), or with Lasem local isen-isen (latohan, watu pecah). The subject matters influenced by Tionghoa Peranakan's visual culture are flower, fan, bamboo, fish, dragon, and phoenix bird. On the use of color, cultural hybridity can be seen from the combination of red color from Tionghoa Peranakan batik visual style with brown from Javanese or Mataraman batik visual style.

This visual culture hybridity is performed by both Chinese and Javanese batik artists in 20 of 21 batik motifs. This shows that the visual style of IPR-certified Lasem batik motifs is actually still expressing the cultural hybridity of Lasem society from the past to the present day. The researchers propose that this visual style hybridity, especially on the subject matter, color, and composition, shall be explored and understood to its symbolic meanings by each batik artist and also the industry entrepreneurs so that the production of latter Lasem batik industry could maintain its geographical indication as a cross-cultural artifact of distinct Chinese and Javanese culture.

There is still the limitation of this research since the observation of visual style hybridity only includes few samples from a wide range of Lasem batik motif designs from past to present. Therefore, the researchers suggest that the observation should be sustained through collaboration between the Lasem batik community, local government, and academic researchers. It is important to document every proof of visual style hybridity on Lasem batik and maintain them as the richness of Lasem geographical indication.

\section{ACKNOWLEDGEMENTS}

1. Kementerian Riset Teknologi dan Pendidikan Tinggi Republik Indonesia that has provided grants to conduct our research on the visual style and meaning of 21 Lasem batik motifs that are certified by HKI.

2. Maranatha Christian University, which had given us an opportunity to acquired grants from Kementerian Riset Teknologi dan Pendidikan Tinggi Republik Indonesia.

3. Dean of Faculty of Art and Design, Maranatha Christian University that allows us to carry out this research.

4. Head of Kantor Dinas Perindustrian Perdagangan Koperasi dan Usaha Mikro Kecil dan Menengah Rembang who provided a file containing 21 Lasem batik motifs that are certified HKI.

5. The artists and batik entrepreneurs in Lasem (Mr. Santoso Hartono, Mr. Fathur Rochim, Mrs. Anisa, Mrs. Priscilla Renny, Mr. Henry Suharto, and Mrs. Sugiyem) who have been willing to be interviewed.

\section{REFERENCES}

Chan, C. S. (2015). Style and creativity in design. Switzerland: Springer International Publishing. doi: 10.1007/978-3-319-14017-9.

Kobayashi, S. (2009). The aim and method of the color image scale. Color Research \& Application, 6(2), 93-107. https://doi.org/10.1002/col.5080060210

Lee, T. (2016). Defining the aesthetics of the Nyonyas' batik sarongs in the straits settlements, late nineteenth to early twentieth century. Asian Studies Review, 40(2), 
173-191. https://doi.org/10.1080/10357823.2016.11 62137.

Lestari, S. N., \& Wiratama, N. S. (2019). Dari opium hingga batik: Lasem dalam "kuasa" Tionghoa abad XIXXX. Patrawidya: Seri Penerbitan Penelitian Sejarah dan Budaya, 19(3), 253-270. Retrieved from https:// patrawidya.kemdikbud.go.id/index.php/patrawidya/ article/view/100.

Lukman, C. C., Setyoningrum, Y., \& Rismantojo, S. (2018). Indonesian Chinese visual language of 'Qilin' on Lasem batik altar cloth (Tok Wi). Journal of Arts and Humanities, 7(9), 84-94. https://doi.org/10.18533/ journal.v7i9.1488.

Maulany, N. N., \& Masruroh, N. N. (2017). Kebangkitan industri batik Lasem di awal abad XXI. Patrawidya, 18(1), 1-12.

McMullen, M. (2016). Intercultural design competence: A guide for graphic designers working across cultural boundaries. The International Journal of Visual Design, 10(3), 19-30. https://doi. org/10.18848/2325-1581/CGP/v10i03/19-30.

Nurhajarini, D. R., Purwaningsih, E., \& Fibiona, I. (2015). Akulturasi lintas zaman di Lasem: Perspektif sejarah dan budaya (kurun niaga-sekarang). Yogyakarta: Kementerian Pendidikan dan Kebudayaan, Direktorat Jenderal Kebudayaan, Balai Pelestarian Nilai Budaya (BPNB) Yogyakarta.
Radford.edu. (n.d). The language of art: Representation, abstraction, line, amd color. Retrieved from https://www.radford.edu/rbarris/art216upd2012/ artlanguageintro.html.

Rahmatullah, I. (2014). Perlindungan indikasi geografis dalam Hak Kekayaan Intelektual (HKI) melalui ratifikasi perjanjian Lisabon. Jurnal Cita Hukum, 2(2), 305-316. https://doi.org/10.15408/jch. v1i2.1470.

Sautier, D., Biénabe, E., \& Cerdan, C. (2011). Geographical indications in developing countries. In E. Barham \& B. Sylvander (Eds.), Labels of Origin for Food: Local Development, Global Recognition (pp. 138153). https://doi.org/10.1079/9781845933524.0138.

Situngkir, H. (2009). The phylomemetics of batik. SSRN Electronic Journal, 1-9. https://doi.org/10.2139/ ssrn. 1481394

Steiner, H. (1995). Cross-cultural design: Communicating in the global marketplace ( $1^{\text {st }}$ Ed.). London: Hong Kong University Press.

Walker, J. A. (2010). Desain, sejarah, budaya. Yogyakarta: Jalasutra. Retrieved from https:/openlibrary. telkomuniversity.ac.id/pustaka/26387/desainsejarah-budaya-cet-1.html.

Zajko, M. (2012). Rose, Gillian, visual methodologies: An introduction to researching with visual materials. Canadian Review of Sociology/Revue Canadienne de Sociologie, 49(4), 449-451. https://doi.org/10.1111/ j.1755-618X.2012.01310.x. 